\title{
Lithium content in potable water, surface water, ground water, and mineral water on the territory of Republic of Macedonia
}

\section{Vesna Kostik, Biljana Bauer', Zoran Kavrakovski ${ }^{2}$}

Institute of Public Health, ${ }^{1}$ Department of Pharmacognosy, Faculty of Pharmacy, ${ }^{2}$ Department of instrumental methods, Faculty of Pharmacy, University of Ss Cyril and Methodius, Skopje, Republic of Macedonia

Address for the Correspondence: Prof. Biljana Bauer, Faculty of Pharmacy, University of Ss Cyril and Methodius, Majka Tereza 47, 1000 Skopje, Republic of Macedonia

E-mail: biba@ff.ukim.edu.mk

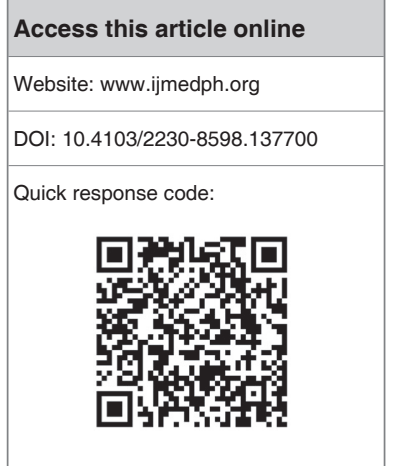

The aim of this study was to determine lithium concentration in potable water, surface water, ground, and mineral water on the territory of the Republic of Macedonia. Water samples were collected from water bodies such as multiple public water supply systems located in 13 cities, wells boreholes located in 12 areas, lakes and rivers located in three different areas. Determination of lithium concentration in potable water, surface water was performed by the technique of inductively coupled plasmamass spectrometry, while in ground water samples from wells boreholes and mineral waters with the technique of ion chromatography. The research shows that lithium concentration in potable water ranging from 0.1 to $5.2 \mu \mathrm{g} / \mathrm{L}$; in surface water from 0.5 to $15.0 \mu \mathrm{g} / \mathrm{L} ;$ ground water from wells boreholes from 16.0 to $49.1 \mu \mathrm{g} / \mathrm{L}$ and mineral water from 125.2 to $484.9 \mu \mathrm{g} / \mathrm{L}$. Obtained values are in accordance with the relevant international values for the lithium content in water.

Key words: Ground water, inductively coupled plasma-mass spectrometry, ion chromatography, lithium, mineral water, potable water, surface water

\section{INTRODUCTION}

Lithium is one of the most important trace elements for the functioning of the human organism. Mainly in the human body is inserted through the food of plant origin (cereals, nuts, vegetables) and water. Surveys conducted by Weiner ${ }^{[1]}$ for the lithium intake in our organism, show that the main part of the lithium intake is inserted through cereals and vegetables 430 and $2900 \mu \mathrm{g} / \mathrm{day}$, while through food from animal origin in our body are inserted insignificant concentration $(2.5 \mu \mathrm{g} /$ day).

As a result, of the importance that lithium has on the functioning of the human body, scientists ${ }^{[2]}$ found that recommended daily dietary intake of lithium (recommended dietary allowance) for adults with an average body mass of $70 \mathrm{~kg}$ is $1 \mathrm{mg} /$ day, which is equivalent to $14.3 \mu \mathrm{g} / \mathrm{kg}$ body mass. The US Environmental Protection Agency established standards for daily intake of lithium which for an adult, weight of $70 \mathrm{~kg}$ ranging from 650 to $3100 \mu \mathrm{g} .{ }^{[3]}$ This concentration of lithium could be provided with food and water intake which contain adequate concentrations of lithium.

Lithium from food or water in the form of soluble salts in the body is being completely absorbed in the gastrointestinal tract (small intestinum) trough $\mathrm{Na}^{+}$channels. Absorbed lithium almost equally is being distributed in the body fluids with little difference between the extra cellular and intracellular fluid. Lithium excretion of the body is carried out through kidneys. According to Hager et al. ${ }^{[4]}$ after the autopsy in men and women who do not have any hetero anamnesis data of prior therapy with lithium preparations, the presence of lithium was found in the following organs: Cerebellum, cerebrum, kidney, thyroid, pancreas, lungs, and bones. From the obtained results can be concluded that the distribution of lithium is greater in women's organs than in men, except in the pancreas. During embryogenesis, the concentration of lithium in the internal organs reaches a maximum concentration in the first trimester of gestation, with a gradual decline to the end of the pregnancy. ${ }^{[5]}$

Biochemical mechanism of action of lithium in the body is very complex and is correlated with the present enzymes, hormones, vitamins and some drugs/medications. Influence of the lithium taken as a remedy on people's mental behavior is due to increasing activity of monoamine oxidase, 
as well as increased transport of folic acid and vitamin B12 in L1210 cells. ${ }^{[6]}$ Biological activity of lithium is due to the powerful polarization feature which is a result of its small ionic radius. Lithium can replace sodium, potassium, magnesium and calcium ions from the enzymes cofactors. ${ }^{[5]}$ According to Ohgami et al. ${ }^{[7]}$ the luck of lithium in the body leads to a change in people's behavior and increased aggression.

Lithium as an element which in nature is found in soil, primary in the clay fraction, ${ }^{[8]}$ potable water, surface water, mineral water, ground water and marine waters as well.

Because the primary source of lithium in humans are water and food, the objective of our research was determination of lithium content in potable water, surface water, ground water from wells boreholes and mineral water on the territory of the Republic of Macedonia, since such data have not been available so far.

\section{MATERIALS AND METHODS}

\section{Water sampling}

The samples of potable water from public water supply systems were investigated, as well as surface water, ground water from wells boreholes and mineral water taken from the territory of the Republic of Macedonia [Figure 1].

Determination of the concentration of lithium was performed in 30 samples of potable water from multiple public water supply systems/network in the Republic of Macedonia (Skopje, Tetovo,
Ohrid, Sveti Nikole, Bitola, Prilep, Strumica, Shtip, Radovish, Kriva Palanka, Kavadarci, Gevgelija and Veles). Determination of lithium concentration in surface water was done on 15 samples taken from several measuring points from the Ohrid Lake, river Lepenec and river Vardar (Gevgelija). The ground water samples from wells boreholes, 35 in total were taken from the territory: Skopje, Kavadarci, Radovish, Kumanovo, Bitola, Sveti Nikole, Prilep, Strumica and Negotino.

The proportion of different water samples in which content of lithium was determined is shown in the following Figure 2.

\section{Analytical methods for determination}

Determination of the concentration of lithium in potable water and surface water was performed with the technique of inductively coupled plasma-mass spectrometry. The NexION® 350D ICPMS features a dual-channel Universal Cell as well the ability to use Dynamic Reaction Cell ${ }^{\mathrm{TM}}$ technology, giving analysts the flexibility to choose Kinetic Energy Discrimination (KED) and/ or the use of a scanning quadrupole in the Dynamic Reaction Cell. These capabilities make it the ideal solution for biomonitoring applications. The limit of detection of lithium with this instrument is $0.05 \mu \mathrm{g} / \mathrm{L}$.

Concentration of lithium in the ground water from wells boreholes and surface water were performed with the technique of ion chromatography with conductivity detector which covers the concentration areas for this type of waters. The performance of this instrument is given in Table 1.

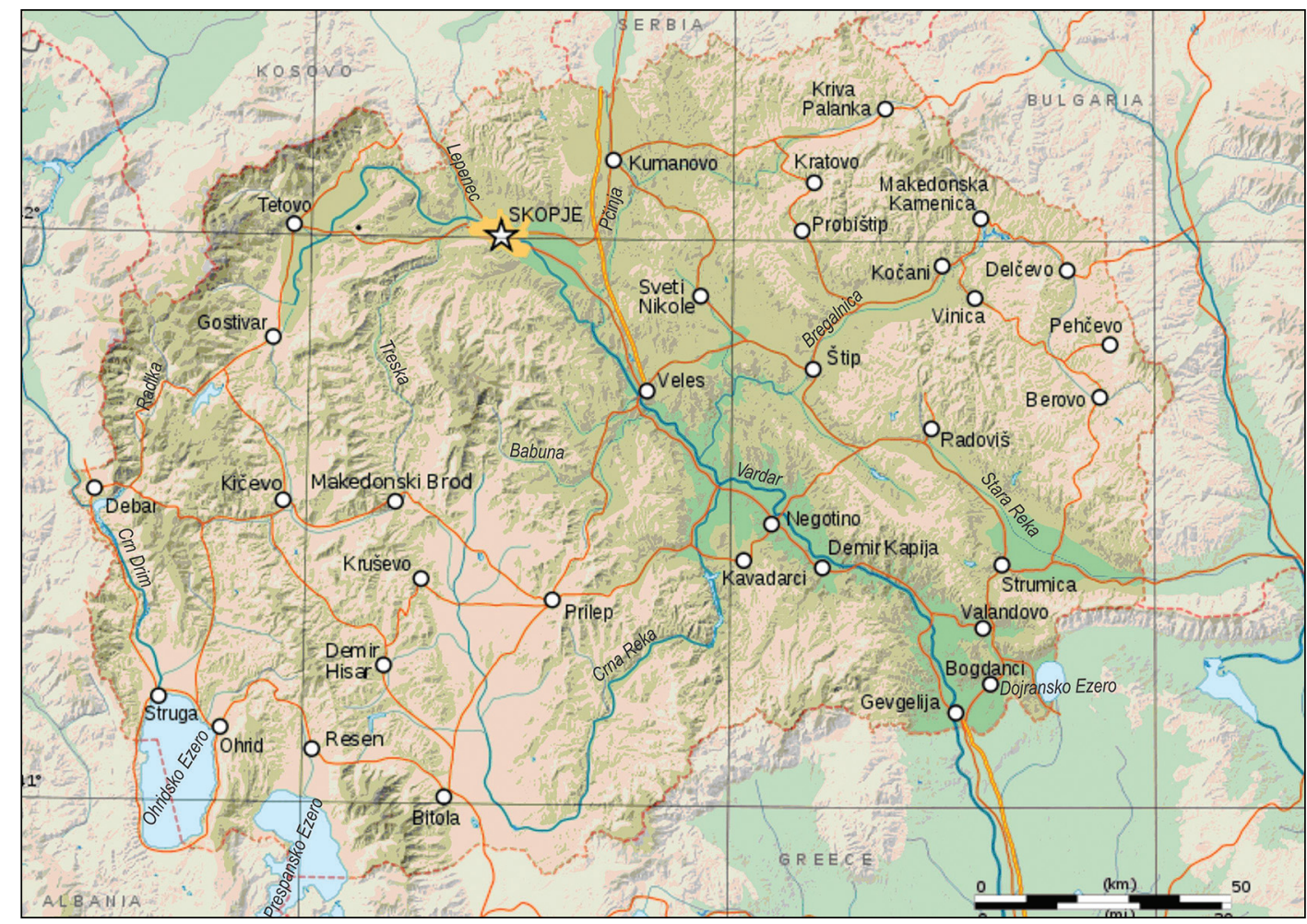

Figure 1: Distribution of sampling sites from the territory of Republic of Macedonia 


\begin{tabular}{llll}
\multicolumn{4}{l}{ Table 1: Instrumental condition for determination of lithium with IC } \\
\begin{tabular}{llll}
\hline Guard column & Analytical column & Eluent & Regenerant \\
\hline CG $163 \mathrm{~mm} \times 50 \mathrm{~mm}$ & CS $163 \mathrm{~mm} \times 250 \mathrm{~mm}$ & $30 \mathrm{mM}$ methanesulfonic acid & $100 \mathrm{mM}$ tetrabutyl ammonium hydroxide \\
\hline IC $=$ lon chromatography & & &
\end{tabular}
\end{tabular}

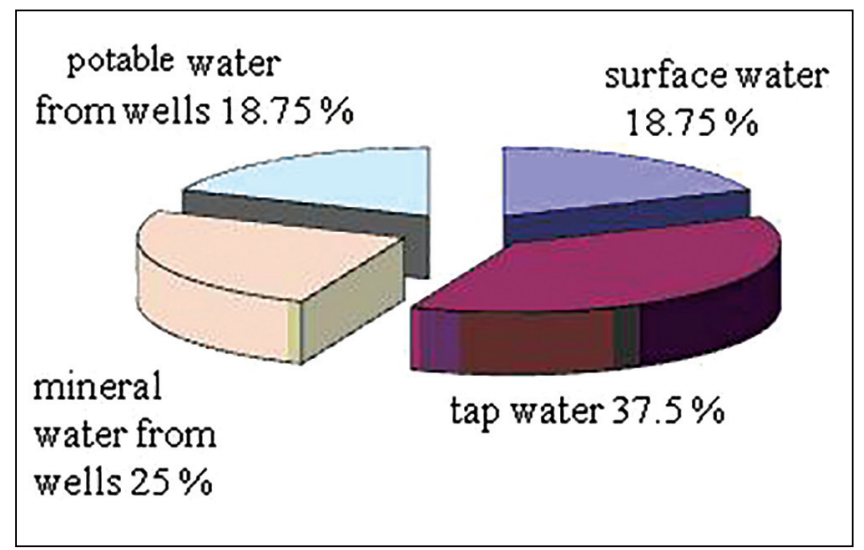

Figure 2: Percentage of the types of water in which is determined the concentration of lithium

\section{RESULTS AND DISCUSSION}

Purpose of our investigation is to determine the concentration of lithium in potable water, surface water, ground water from wells boreholes and mineral water on the territory of the Republic of Macedonia. The results of the tests are given in Tables 2-5. Regulations for the water quality in the Republic of Macedonia provide no lithium content data. Therefore, our results were compared with literature data.

Lithium was found in all analyzed water samples from the territory of Republic of Macedonia. Its concentrations depended on the type of water sample, which was analyzed [Table 6]. The heterogeneity of the results in the general research with a high coefficient of variation values implied that differences in the location and period of sampling had a major influence on the lithium content.

Research shows that concentration of lithium in the potable water from public water supply systems in the Republic of Macedonia ranging from 0.11 to $5.20 \mu \mathrm{g} / \mathrm{L}$ [Table 2]. In some regions of the world, ${ }^{[7,9]}$ in order to increase the daily intake of lithium in human nutrition, lithium is added as a supplement in the potable water (tap water), with the final concentration of lithium in water of $170 \mu \mathrm{g} / \mathrm{L}$. Low lithium concentration in potable water from multiple public water supply systems from the network in the Republic of Macedonia points to the possibility for a beginning of the enrichment of Macedonian potable water with lithium.

Determination of the concentration of lithium was performed in 30 samples of potable water from multiple public water supply systems/ network in the Republic of Macedonia. By calculating the average values of the lithium concentration according to the location the follow hierarchical lithium concentration gradient is obtained Skopje $2.84 \mu \mathrm{g} / \mathrm{L}$, Kavadarci $1.81 \mu \mathrm{g} / \mathrm{L}$, Sveti Nikole $1.56 \mu \mathrm{g} / \mathrm{L}$, Gevgelija $1.33 \mu \mathrm{g} / \mathrm{L}$, Shtip $1.00 \mu \mathrm{g} / \mathrm{L}$, Strumica $0.67 \mu \mathrm{g} / \mathrm{L}$, Tetovo $0.49 \mu \mathrm{g} / \mathrm{L}$,

\begin{tabular}{|c|c|c|}
\hline Location & Period & $\begin{array}{c}\text { Lithium } \\
\text { concentration }\end{array}$ \\
\hline Ohrid/Gradishte & May 2010 & 0.25 \\
\hline Ohrid/Hotel Metropol & May 2010 & 0.11 \\
\hline Tetovo/City tap & April 2010 & 0.30 \\
\hline Skopje/Hotel Continental & April 2009 & 5.20 \\
\hline Tetovo/Periphery & May 2010 & 0.40 \\
\hline Tetovo/Center & May 2010 & 0.78 \\
\hline Sveti Nikole/City tap & April 2009 & 1.56 \\
\hline Skopje/Butel & April 2011 & 2.40 \\
\hline Skopje/Karposh & April 2011 & 2.89 \\
\hline Bitola/Center restaurant & April 2009 & 0.23 \\
\hline Strumica/Hotel Sirius & April 2010 & 0.90 \\
\hline Skopje/Center & September 2011 & 1.20 \\
\hline Skopje/Chair & November 2011 & 1.98 \\
\hline Prilep/Center & May 2010 & 0.23 \\
\hline Strumica/Hotel Sirius & April 2009 & 0.54 \\
\hline Strumica/Barracks & April 2010 & 0.67 \\
\hline Strumica/Market-place & May 2011 & 0.56 \\
\hline Radovish/Restaurant & April 2009 & 0.43 \\
\hline Radovish/Household & April 2010 & 0.48 \\
\hline $\begin{array}{l}\text { Shtip/Restaurant at cultural } \\
\text { home Aco Shopov }\end{array}$ & April 2010 & 0.89 \\
\hline Shtip/Periphery (entry) & April 2010 & 1.12 \\
\hline Kriva Palanka/Center & April 2009 & 0.35 \\
\hline Veles/Intercity bus station & April 2009 & 0.15 \\
\hline Kriva Palanka/Center & May 2010 & 0.22 \\
\hline Skopje/Center & April 2010 & 2.56 \\
\hline Skopje/Gjorche Petrov & April 2010 & 3.65 \\
\hline Kavadarci/Center Restaurant & April 2010 & 1.78 \\
\hline Gevgelija/Center Restaurant & April 2009 & 1.12 \\
\hline Kavadarci/Center & April 2010 & 1.85 \\
\hline Gevgelija/Center & May 2010 & 1.55 \\
\hline
\end{tabular}

Radovish $0.45 \mu \mathrm{g} / \mathrm{L}$, Kriva Palanka $0.28 \mu \mathrm{g} / \mathrm{L}$, Bitola $0.23 \mu \mathrm{g} / \mathrm{L}$, Prilep $0.23 \mu \mathrm{g} / \mathrm{L}$, Ohrid $0.18 \mu \mathrm{g} / \mathrm{L}$ and Veles $0.15 \mu \mathrm{g} / \mathrm{L}$. If the territory of Republic of Macedonia is separated with river Vardar on the west and east part the estimated lithium concentrations of potable water are little bit higher in the east part $(1.69 \mu \mathrm{g} / \mathrm{L}>1.34 \mu \mathrm{g} / \mathrm{L})$.

Lithium concentration in surface water of 15 samples taken from several measuring points from the Ohrid Lake, river Lepenec and river Vardar (Gevgelija) are presented in Table 3. Lithium concentrations in surface water varied from 0.53 to $15.03 \mu \mathrm{g} / \mathrm{L}$. Highest average lithium concentration was obtained on the measuring points at river Vardar near Gevgelija of $13.09 \mu \mathrm{g} / \mathrm{L}$ and the lowest average lithium concentration of $1.07 \mu \mathrm{g} / \mathrm{L}$ was obtained in the measuring points at Ohrid Lake. 


\begin{tabular}{llc}
\multicolumn{3}{l}{ Table 3: Results of determination of lithium in } \\
surface water in the republic of macedonia ( $\mu \mathrm{g} / \mathrm{L})$
\end{tabular}

Table 4: Results of determination of lithium in
ground mineral water from wells in the Republic
of Macedonia, categorized as mineral water ( $\mu$ g/L)

Lithium composition of 35 in total ground water samples from wells boreholes, are presented in Tables 4 and 5. Twenty samples of ground water are categorized as mineral water, the rest 15 as potable

\begin{tabular}{llc}
$\begin{array}{l}\text { Table 5: Results of determination of the li in } \\
\text { ground water from wells in the republic of }\end{array}$ \\
\begin{tabular}{l} 
macedonia, categorized as potable water ( $\mu \mathrm{g} / \mathrm{L})$ \\
\hline Location
\end{tabular} & Time & $\begin{array}{c}\text { Lithium } \\
\text { concentration }\end{array}$ \\
\hline Sveti Nikole well 1 & April 2009 & 17.56 \\
Sveti Nikole well 2 & April 2009 & 17.28 \\
Prilep well 1 & April 2009 & 23.50 \\
Prilep well 2 & April 2009 & 28.98 \\
Radovish well 1 & Maj 2009 & 19.40 \\
Radovish well 2 & Maj 2009 & 21.20 \\
Radovish well 1 & September 2010 & 16.05 \\
Petrovec well 1 & April 2009 & 34.40 \\
Petrovec well 2 & April 2010 & 24.80 \\
Petrovec well 2 & September 2011 & 22.56 \\
Rosoman, Kavadarci well 1 & April 2011 & 27.98 \\
Rosoman, Kavadarci well 2 & April 2011 & 38.90 \\
Kumanovo well 1 & April 2009 & 41.60 \\
Negotino well 1 & April 2009 & 17.65 \\
Bitola well 1 & September 2009 & 49.10 \\
\hline
\end{tabular}

\begin{tabular}{l} 
Table 6: Statistical processing of the results of \\
determination of lithium in potable water, surface \\
water, ground water and mineral water on the \\
territory of republic of macedonia \\
\hline \multicolumn{2}{c}{ Lithium concentration } \\
\hline Public water supply systems \\
Average \\
CV \\
Surface water \\
Average \\
CV \\
Ground mineral water from wells \\
Average \\
CV \\
Ground water from wells \\
Average \\
CV \\
\hline CV = Coefficient of variation \\
\end{tabular}

water according to our regulation limit. ${ }^{[10]}$ Lithium levels were very consistent at about $125.20-484.90 \mu \mathrm{g} / \mathrm{L}$ in mineral ground water. By calculating the average values of the lithium concentration according to the location of mineral ground water the follow hierarchical lithium concentration gradient is obtained Bitola $436.47 \mu \mathrm{g} / \mathrm{L}$,

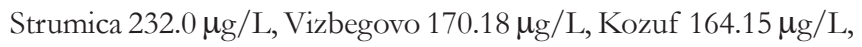
Katlanovo 147.63 $\mu \mathrm{g} / \mathrm{L}$ and Kumanovo $143.87 \mu \mathrm{g} / \mathrm{L}$. The estimated lithium concentrations of mineral ground water are higher in the west part of the territory of Republic of Macedonia $(300.31 \mu \mathrm{g} / \mathrm{L}$ $>173.59 \mu \mathrm{g} / \mathrm{L})$.

The obtained results [Table 5] for potable ground water were somewhat lower from 16.05 to $49.10 \mu \mathrm{g} / \mathrm{L}$. According to the location of mineral ground water the follow hierarchical lithium concentration gradient is obtained Bitola $49.10 \mu \mathrm{g} / \mathrm{L}$, Kumanovo $41.96 \mu \mathrm{g} / \mathrm{L}$, Kavadarci, $33.44 \mu \mathrm{g} / \mathrm{L}$, Petrovec $27.25 \mu \mathrm{g} / \mathrm{L}$, Prilep 
$26.24 \mu \mathrm{g} / \mathrm{L}$, Radovish $18.88 \mu \mathrm{g} / \mathrm{L}$, Negotino $17.65 \mu \mathrm{g} / \mathrm{L}$ and Sveti Nikole $143.87 \mu \mathrm{g} / \mathrm{L}$. The estimated lithium concentrations of potable ground water are higher in the west part of the territory of Republic of Macedonia $(31.61 \mu \mathrm{g} / \mathrm{L}>26.38 \mu \mathrm{g} / \mathrm{L})$.

Research shows that concentration of lithium in the potable water, surface water, water from wells boreholes and mineral water from the territory of Republic of Macedonia is in accordance with the relevant international values for the content of lithium in water. ${ }^{[7,11]}$

\section{CONCLUSION}

If the estimated lithium concentrations values from the east and west part from the territory of Republic of Macedonia were compared could be noticed that more lithium was found in the west part.

Macedonian potable water can serve as bad source of lithium able to supplement recommended daily dietary intake of lithium in the diet.

\section{REFERENCES}

1. Weiner ML. Overview in lithium toxicology. In: Schrauzer GN, Klippel KF, editors. Lithium in Biology and Medicine. Weinheim: VCG Verlag; 1991. p. 83-99.

2. Hager ED, Dziambor H, Winkler P, Macholdt K: Effekt von Lithium carbonat bei Patienten mit niedriger Thrombozytenzahl nach einer. In: Anke M,
Arnhold W, Bergmann H. Proceedings Mengen und Spurenelemente, 20 Jahrestagung. Leipzig: Schubert - Verlag, 2000. p. 119-29.

3. Lu FC, Kacew S. Lu's Basic Toxicology: Fundamentals, Target Organs and Risk Assessment. $4^{\text {th }}$ ed. London: Taylor \& Francis; 2003.

4. Hager ED, Dziambor H, Winkler P, Höhmann D, Macholdt K. Effects of lithium carbonate on hematopoietic cells in patients with persistent neutropenia following chemotherapy or radiotherapy. J Trace Elem Med Biol 2002;16:91-7.

5. Vanyo L, Vu T, Ramos M, Amin J, Conners S, Baterman R, et al. Lithium induced perturbations of vitamin $B_{12}$, folic acid and DNA metabolites. In: Schrauzer GN, Klippel KF, editors. Lithium in Biology and Medicine. Weinheim: VCG Verlag; 1991. p. 17-30.

6. Klemfuss $H$, Greene KE. Cation affecting lithium toxicity and pharmacology. In: Schrauzer GN, Klippel KF, editors. Lithium in Biology and Medicine. Weinheim: VCG Verlag; 1991. p. 133-45.

7. Ohgami H, Terao T, Shiotsuki I, Ishii N, Iwata N. Lithium levels in drinking water and risk of suicide. Br J Psychiatry 2009;194:464-5.

8. Roberts FI. Mineralization of the Woolgangie-Yilma Area, Eastern Goldfield Granite Greenstone Terrain. Geological Survey Western Australia. Record; 2004. p. 6.

9. Anke M, Arnhold B, Glei M, Müller M, Illing H, Schafer U, et al. Essentiality and toxicity of lithium. In: Kosla T, editor. Lithium in the Tropic-ChainSoil-Plant-Animal-Man, Proceedings of International Symposium; 1998. Warshaw, Poland; 1998. p. 17-42.

10. Regulation for water safety, Sluzben Vesnik na Republika Makedonija, 46/08.

11. Schrauzer GN. Lithium: occurrence, dietary intakes, nutritional essentiality. J Am Coll Nutr 2002;21:14-21.

How to cite this article: Kostik V, Bauer B, Kavrakovski Z. Lithium content in potable water, surface water, ground water, and mineral water on the territory of Republic of Macedonia. Int J Med Public Health 2014;4:189-93.

Source of Support: Nil, Conflict of Interest: None declared. 